\title{
Retraction Note: Agricultural river pollution based on SAR image and analysis of milk protein nutrition consumer market
}

\author{
Xiujuan Liu ${ }^{1}$
}

Published online: 29 November 2021

C) Saudi Society for Geosciences 2021

Retraction Note: Arabian Journal of Geosciences (2021) 14: 1596 https://doi.org/10.1007/s12517-021-07952-0

The Editor-in-Chief and the Publisher have retracted this article because the content of this article is nonsensical. The peer review process was not carried out in accordance with the Publisher's peer review policy. The author has not responded to correspondence regarding this retraction.

The original article can be found online at https://doi.org/10.1007/ s12517-021-07952-0.

Xiujuan Liu

hbaulxj@163.com

1 College of Economics and Management, Hebei Agricultural University, Baoding 071000, Hebei, China 